\title{
Correction to: Pexidartinib: First Approval
}

\author{
Yvette N. Lamb ${ }^{1}$
}

Published online: 28 February 2020

(c) Springer Nature 2020

\section{Correction to: Drugs (2019) 79:1805-1812 https://doi.org/10.1007/s40265-019-01210-0}

The article Pexidartinib: First Approval, written by Yvette N. Lamb was originally published Online First without Open Access. After publication online Daiichi Sankyo, Inc., requested that the article be Open Choice to make the article an open access publication. Post-publication open access was funded by Daiichi Sankyo, Inc. The article is forthwith distributed under the terms of the Creative Commons Attribution-NonCommercial 4.0 International License (http:// creativecommons.org/licenses/by-nc/4.0/), which permits any noncommercial use, duplication, adaptation, distribution and reproduction in any medium or format, as long as you give appropriate credit original author(s) and the source, provide a link to the Creative Commons licence and indicate if changes were made.
The original article can be found online at https://doi.org/10.1007/ s40265-019-01210-0.

Yvette N. Lamb

dru@adis.com

1 Springer Nature, Private Bag 65901, Mairangi Bay, Auckland 0754, New Zealand
The original article has been corrected.

Open Access This article is licensed under a Creative Commons Attribution-NonCommercial 4.0 International License, which permits any non-commercial use, sharing, adaptation, distribution and reproduction in any medium or format, as long as you give appropriate credit to the original author(s) and the source, provide a link to the Creative Commons licence, and indicate if changes were made. The images or other third party material in this article are included in the article's Creative Commons licence, unless indicated otherwise in a credit line to the material. If material is not included in the article's Creative Commons licence and your intended use is not permitted by statutory regulation or exceeds the permitted use, you will need to obtain permission directly from the copyright holder.To view a copy of this licence, visit http://creativecommons.org/licenses/by-nc/4.0/. 